\title{
Psychological Features of the Professional Communicative Activity of the Pharmaceutical Worker
}

\section{Психологічні особливості професійної комунікативної діяльності фармацевтичного працівника}

Nataliia Honcharenko

Ph.D. in Psychology, Assistant Professor of the Department of Military Pharmacy

\author{
Наталія Гончаренко \\ кандидат психологічних наук, \\ доцент кафедри військової \\ фармації
}

E-mail: goncarenkonatplia@gmail.com orcid.org /0000-0002-9551-4113

Ukrainian Military Medical Academy, Kyiv, Ukraine 45/1, Moscow street, Kyiv, 01015
Українська військово-ледична акаделія, л. Киӥв, Украӥна вул. Московська, 45/1, м. Київ, 01015

Original manuscript received May 04, 2019 Revised manuscript accepted May 23, 2019

\section{ABSTRACT}

The research paper presents the results of the analysis of scientific sources on theoretical, methodological and applied aspects of the range of problems. The essence and specifics of professional communicative activities of pharmacists are determined, their professional communicative qualities and abilities, as well as psychological characteristics of a person, which form the communicative competence of the pharmacist are described. Theoretical and experimental approaches to the determination of the problem have been clarified. It is emphasized that the communicative competence of a pharmacist is a professionally significant quality, since his professional activities involves communi- 
cation: with patients, their relatives, doctors. It is noted that the professional communicative qualities of pharmacists constitute a psychological portrait of future pharmacists. The content and structure of communicative competence is determined. It is noted that the components of professional communicative competence of future pharmacists are the motivational, cognitive and professional communicative components that play the role of criteria for its development. The basic conditions for the formation of the communicative competence of the future pharmaceutical worker are determined. It is stated that among professionally significant psychological characteristics of the personality of a pharmaceutical worker, we can single out the ability to communicate, establish and develop relationships with other people, emotional stability, balance in the absence of impulsivity, excessive emotional expressiveness, the ability to "read" non-verbal language and use it in professional activities, communicative tolerance, sensitivity to deviation (neglect). The parameters of paralinguistic communication that are professionally important for a pharmaceutical worker and the peculiarities of using the means of non-verbal communication in their professional activities are outlined in the research paper.

Key words: communication, communicative activities of future pharmacists, competence, professional competence, professional communicative competence of pharmacists, communicative tolerance, affiliation, non-verbal language of communication.

\section{Вступ}

На сьогодні вітчизняний фармацевтичний ринок диктує необхідність підготовки фахівців, які могли б не тільки готувати ліки, а й установлювати професійні контакти з відвідувачами аптек, лікарями, представниками фрармацевтичних підприємств i державних установ. Комунікативна компетентність провізора (фармацевта) - професійно значуща якість. Професія провізора (фармацевта) передбачає тією чи іншою мірою виражене інтенсивне i тривале спілкування: 3 хворими, їх родичами, лікарями. Від уміння спілкуватися, встановлювати і розвивати взаємовідносини з людьми багато в чому залежить професійна успішність провізора (фармацевта). Гарний психологічний контакт із відвідувачем аптеки допомагає надати якісну фармацевтичну допомогу. Вміння спілкуватися, або комунікативна компетентність, забезпечує взаєморозуміння, 
довіру в стосунках, ефективність у вирішенні поставлених завдань (Шматенко \& Гончаренко, 2014).

На думку багатьох, як вітчизняних, так і зарубіжних авторів, когнітивний i моральний розвиток майбутнього фармацевтичного працівника передбачає інтеріоризацію ще у процесі здобуття ним професійної освіти (David A. Latif, 2000). Етико-моральні норми є регуляторами як у процесі здійснення фармацевтичної опіки, так і у процесі ефективного надання відвідувачам аптеки фармацевтичної допомоги. Психологічну та соціальну підтримку фармацевтичного працівника, на думку науковців, доречно супроводжувати засобами коучінгу (Laurence, Brunton, Lazo, Parker \& Goodman, 2006; Magola, 2018: 117-123).

Актуальність проблеми комунікативної компетентності у сфері фармацевтичної діяльності й освіти привернула увагу багатьох учених до її досліджень, що проводилися з різних точок зору низкою вітчизняних і зарубіжних науковців.

Комунікативну компетентність науковці розглядають як умову ефективного спілкування в міжособистісних стосунках (Альохіна, 2013), як засіб забезпечення успішної професійної діяльності (Максименко, 2005). Психологічні основи формування соціально-комунікативної компетентності досліджували І. Зимня (Зимня, 2006), Л. Пляка (Пляка, 2009), В. Тюріна (Тюріна, 2009). Психологічні засади формування іншомовної комунікативної компетенції майбутніх фахівців соціономічних професій досліджувала Л. Онуфрієва (Онуфрієва, 2017). Автори акцентували увагу на тому, що у фахівців, які належать до типу професій «людина - людина», комунікативна компетентність $є$ обов'язковою якістю особистості, що забезпечує ефективність їх професійної діяльності.

Мета статті - здійснити аналіз психологічних особливостей комунікативної діяльності провізорів і характеристик особистості, що формують комунікативну компетентність фармацевтичного працівника. 


\section{Завдання статті}

3'ясувати психологічні особливості комунікативної діяльності фармацевтичних працівників.

\section{Методи та методики дослідження}

У дослідженні використано теоретичний аналіз наукової літератури, що дало змогу з'ясувати підходи сучасних науковців до осмислення змісту комунікативної діяльності фармацевтичних працівників та їі психологічних особливостей.

\section{Результати та дискусії}

У вітчизняних і зарубіжних працях із прикладними аспектами психології, педагогіки, лінгвістики та фармації розкрито теоретико-методичні основи підготовки майбутніх фахівців до комунікативно-професійної діяльності. Науковці емпірично досліджували комунікативний потенціал у контексті комунікативних якостей і здібностей, комунікативної компетентності, психологічних особливостей професійного ділового спілкування, формування культури ділового спілкування через розвиток мовлення (Альохіна, 2013; Пляка, 2011; Magola, 2018).

Успішність професійної комунікативної діяльності провізорів багато в чому залежить від рівня розвитку їх професійних комунікативних здібностей і психологічних характеристик, що формують уміння фахівця легко і швидко встановлювати контакти із суб'єктами професійного спілкування. До професійних комунікативних здібностей майбутніх провізорів, на думку науковців, можна віднести міжособистісні, перцептивні, психотехнічні, предметно-пізнавальні й інтерактивні здібності. Кожна комунікативна здібність передбачає наявність у фахівців професійних комунікативних якостей та індивідуальнопсихологічних характеристик. Професійні комунікативні якості майбутніх провізорів характеризують психологічну й індивідуальну спрямованість, становлять психологічний 
портрет майбутніх провізорів, що включає комплекс професійно-спрямованих, індивідуально-психологічних і моральних якостей (Пляка, 2010).

Компетентність - це рівень психічного розвитку майбутнього фахівця, його загальна здатність, що базується на відповідних професійних знаннях, уміннях і навичках, здібностях особистості й здійснюється у процесі професійної діяльності. Компетентність є тим індикатором, який дає змогу визначити рівень готовності майбутнього провізора до професійної діяльності (Альохіна, 2013; Пляка, 2011; Magola, 2018).

Професійна комунікативна компетентність необхідна для успішної роботи за фахом не лише провізора, а й будьякого фахівця, який працює в системі «людина - людина» . Ïї низький рівень вимагає розробки дієвих методів адаптації майбутніх фахівців до комунікативної професійної діяльності. 3 цією метою науковці ввели в медичні та фармацевтичні програми активне навчання комунікаціям із застосуванням дидактичних методів: рольові ігри за участю студентів-колег для надання медичної та фармацевтичної допомоги пацієнтам і медичного консультування, деонтологічний аналіз відеозаписів, проведення дискусій. Такі дидактичні методи сприяють формуванню комунікативних навичок, розвивають самостійність, критичне мислення, здатність до емпатії та «орієнтовані на конкретні комунікаційні компетенції, а не на загальні навички спілкування» (Wloszczak-Szubzda, 2013: 193-194).

Як зазначають науковці, складниками професійної комунікативної компетентності майбутніх провізорів є мотиваційний, когнітивний і професійно-комунікативний компоненти, що відіграють роль критеріїв їі розвитку (Альохіна, 2013; Кайдалова \& Пляка, 2011).

Уміння спілкуватися, або комунікативна компетентність, забезпечує взаєморозуміння, довіру в стосунках, ефективність у вирішенні поставлених завдань. Відвідувач аптеки орієнтується у виборі аптеки не лише на професіо- 
налізм, але й на суто людські, особистісні якості провізора (фармацевта): наскільки він викликає довіру і повагу, уважний і чуйний, приваблює до себе, викликає бажання спілкуватися. В окремих випадках психологічні якості провізора (фармацевта) для хворого важливіші, ніж професійні знання, уміння, навики. Хворі виокремлюють такі якості провізора (фармацевта), що асоціюються у них 3 цією професією: повага, увага до відвідувачів аптеки, любов до професії, доброта, ввічливість, душевність, тобто переважно комунікативно значущі риси. Якості особистості провізора (фармацевта) оцінюються надзвичайно високо.

Адекватна комунікація передбачає правильне розуміння відвідувача аптеки і відповідне реагування на його поведінку. Незалежно від того, у якому душевному стані знаходиться відвідувач аптеки, відчуває він гнів чи сум, неспокій, тривогу чи відчай, провізор (фармацевт) повинен уміти з ним взаємодіяти.

У зв’ язку з цим можна виокремити професійно значущі психологічні характеристики особистості фармацевтичного працівника, які формують його комунікативну компетентність. Серед них колунікативна толерантність (як один з аспектів комунікативної компетентності) - терпимість, поблажливість тощо. Комунікативна толерантність показує, у якій мірі провізор (фармацевт) переносить суб’єктивно небажані, неприйнятні для нього індивідуальні особливості відвідувачів аптеки, негативні якості, вчинки, які засуджують, звички, чужі стилі поведінки і стереотипи мислення. Хворий може викликати різні почуття, подобатися чи не подобатися, може бути приємним або неприємним для провізора (фармацевта), але в будь-якому випадку психологічна підготовка останнього повинна допомогти попередити виникнення конфліктної ситуації.

В основі формування комунікативної компетентності лежить така психологічна характеристика особистості, як прагнення перебувати разом з іншими людьми, належати до якої-небудь соціальної групи, встановлювати емоційні 
взаємовідносини з оточуючими, бути в системі міжособистісних відносин. Ця психологічна риса, потреба в інших людях, прагнення до взаємодії з ними, в літературі позначається терміном «афіліація» - потреба людини бути в суспільстві інших людей, прагнення до «приєднання» . Внутрішньо (психологічно) афіліація виступає у вигляді почуття прихильності й вірності, а ззовні - у товариськості, бажанні співпрацювати з іншими людьми, постійно перебувати разом із ними, в особливостях невербальної поведінки (Москаленко, 2008).

Інша психологічна характеристика, що забезпечує комунікативну компетентність провізора (фармацевта), це емоційна стабільність, урівноваженість за відсутності імпульсивності, надмірної емоційної експресивності, зі збереженням контролю над емоційними реакціями і поведінкою загалом. Емоційна стабільність допомагає провізору (фармацевту) уникати у взаємовідносинах із хворими «психологічних зривів», конфліктів. Інтенсивні емоційні реакції не тільки руйнують довіру хворого, лякають і насторожують його, але й астенізують, утомлюють. Навпаки, душевна рівновага провізора (фармацевта), його спокійна доброзичливість, емоційна стабільність викликають у відвідувача аптеки почуття надійності, що сприяє встановленню довірливих стосунків. Хворі, з їх нестабільною психікою, тривожністю, невпевненістю, неспокоєм, лабільністю емоційних реакцій, потребують стабілізуючої впевненості провізора (фармацевта) (Шматенко \& Гончаренко, 2014).

Психологічною якістю, яка забезпечує адекватну комунікацію в системі взаємовідносин «провізор (фармацевт) - хворий», є також елпатія - здатність до співчуття, співпереживання, своєрідна психологічна «включеність» у світ переживань хворого. Емоційна співучасть допомагає встановити психологічний контакт із хворим, отримати більш точну і повну інформацію про нього і його стан, навіяти впевненість у компетентності провізора (фармацевта), вселити віру в одужання. 
За результатами зарубіжних досліджень, емпатійний провізор успішно рефлексує очікування відвідувачів аптеки, їхні емоційні стани й ефективно застосовує індивідуальний підхід і співпрацю у взаємодії з ними, орієнтуючись у своїй професійній комунікативній діяльності на етичні цінності (Koda-Kimble, 2013; Singer, 2005; A. Robert, 2002; M. Robert, 2008; Evans, 2008).

Зарубіжні науковці часто виявляють інтерес до дослідження умов формування такого рівня професійної відповідності фармацевтичних працівників, за якого вони здатні проявити комунікативну толерантність, милосердя, високий рівень комунікативно-професійної культури та забезпечити безпеку відвідувачу аптеки. Суттєвими умовами успішного засвоєння провізорами-інтернами деонтологічної професійно-комунікативної культури фармацевтичного працівника є вивчення ними кодексів етики та науково-фармацевтичної літератури з етичних питань (Singer, 2005; Robert, 2008; Evans, 2008).

Психологічною характеристикою, яка впливає на комунікативну компетентність провізора (фармацевта), є і сенситивність до відхилення (знехтування). Здатність індиферентно сприймати негативне відношення оточуючих, зокрема відвідувачів аптеки, сприяє підвищенню рівня стресостійкості фармацевтичного працівника та збереженню його психічного здоров' я.

Однією з умов формування комунікативної компетентності є вміння «читати» невербальну лову колунікаціі. До засобів невербальної комунікації належать пози, міміка, жести, погляд.

Важливе значення в оцінці готовності до доброзичливого спілкування партнера по спілкуванню має поза. Пози поділяються на природні й неприродні. Природня поза вільна, невимушена - характеризує психологічний комфорт, відсутність напруги і схиляє до спілкування. Навпаки, поза неприродна - незвичайна, дивна, безглузда - до 
спілкування не схиляє, вона свідчить про напругу, психологічний дискомфорт.

Пози бувають симетричні й асиметричні. Симетрична поза нівелює індивідуальні відмінності, роблячи людей дещо схожими один на одного, вона передбачає офіційну, регламентовану взаємодію. Їй надають перевагу люди закриті, інтровертовані, стримані, з високим контролем, які відрізняються обережністю у взаємовідносинах, недовірою, підозрілістю, які не схиляють до близькості й співробітництва, а тому довіри не викликають. Поза асиметрична, навпаки, свідчить про індивідуальні особливості, відкритість для спілкування, готовність до співробітництва.

Пози бувають також відкриті й закриті. Закрита поза вказує на небажання спілкуватися, уникнення взаємостосунків з оточуючими. Закрита поза характеризується такими ознаками: схрещені на грудях руки, схрещені ноги (нога на ногу); кисті рук у кишенях, сховані за спину; корпус тіла і голова повернуті в сторону від партнера; погляд спрямований у підлогу, в вікно. Закрита поза не схиляє до спілкування. Відкрита поза характеризується протилежними специфічними ознаками: корпус тіла і голова повернуті в сторону співрозмовника, прямий погляд в обличчя тощо. Відкрита поза свідчить про готовність до контактів, до міжособистісної взаємодії. Провізору краще використовувати в ситуації професійного спілкування з відвідувачем аптеки природні, асиметричні, відкриті пози, що схиляють до спілкування, не викликають напруги чи недовіри, створюють кращі умови для взаємодії. Особливо важливо це на початку спілкування, при встановленні психологічного контакту з хворим (Пляка, 2009).

Жести також відіграють важливу роль у спілкуванні. Усі різноманітні жести умовно поділяються на дві групи: комунікативні й експресивні. Комунікативні жести мають свій зміст, зрозумілий оточуючим. Вони використовуються в мові разом зі словами, а іноді замість слів, що допомагає спілкуванню. Існують жести, прийняті у деяких професій- 
них групах, наприклад, у спортсменів чи автомобілістів. До експресивних належать жести, які не мають визначеного, зрозумілого для всіх змісту. Вони виражають стан людини, досить індивідуальні, рано формуються в онтогенезі й відносно незмінні впродовж усього життя. Яскравість, вираженість експресивної жестикуляції визначається особливостями темпераменту, актуальним станом, а також рівнем освіти. Освічені люди з багатим словниковим запасом, точно знаючи значення слів, не мають потреби підкріплювати мову жестами. Особам із невисоким рівнем освіти, обмеженим словниковим запасом важко підібрати потрібні слова. Вони часто допомагають собі в цьому, супроводжуючи мову жестами (Шматенко \& Гончаренко, 2014).

Міміка - це скоординовані рухи м'язів обличчя, які відображають емоції, настрій, почуття. Найбільш інформативною є міміка нижньої частини обличчя: лінія рота, крила носа, носо-губна складка від крил носа до куточків губ, підборіддя. Найінформативніша деталь обличчя людини - лінія рота. У разі гарного самопочуття і високого життєвого тонусу лінія рота - пряма. Опущені вниз куточки губ - ознака, що характеризує стан печалі, депресії чи втоми. Надмірна усміхненість із постійно піднятими куточками губ, як правило, означає підвищену залежність від оточуючих із прагненням отримати їх схвалення і підтримку, в основі якої лежить невпевненість у собі.

Мілічний колплекс емоції гніву загалом включає в себе вертикальні зморшки на лобі, насуплені брови, примружені очі зі зморшками в їх куточках, стиснену лінію губ.

Погляд - важливий елемент невербального спілкування, саме погляд в очі допомагає відчути психологічний контакт зі співрозмовником. «Бігаючий» погляд, як правило, є ознакою дискомфорту в ситуації спілкування і свідчить про амбівалентну установку стосовно оточуючих. Оптимальна тривалість погляду - 3 с. Зазвичай, цього буває достатньо, щоб відчути психологічний контакт із партнером, не викликаючи у нього роздратування. Погляд, який про- 
довжується від 3 до 10 с, називається пильним і викликає у співрозмовника напруження й дискомфорт. Погляд, який триває понад 10 с, виражає або конфронтацію, або агресивний виклик.

Люди спокійні, з високою самооцінкою, задоволені собою та своєю життєвою ситуацією при міжособистісній взаємодії дивляться в очі співбесіднику частіше, ніж невпевнені в собі, емоційно нестійкі, незадоволені. У процесі вербального контакту той, хто говорить, частіше дивиться на того, хто слухає.

Серед параметрів паралінгвістичної колунікацї виокремлюють чотири значущі ознаки мови: гучність, її темп, ритм, пауза. Поєднання гучності й частоти мови сприймається як ознака конфліктних взаємовідносин і викликає відповідну агресивну реакцію. Сказане на тлі гучної мови ще гучнішим голосом також викликає у відповідь агресію. Те, що на тлі гучної мови сказане тихішим голосом, викликає у відповідь реакцію уваги. Як зазначає низка авторів, чим більше в мові запинок, подібних слів, тим менший ступінь довіри до отриманої інформації і менш компетентним здається співрозмовник (Кайдалова \& Пляка, 2011).

До психологічних особливостей, які знижують колунікативну колпетентність провізора (фарлаиевта), належать такі.

Тривога - це емоція, спрямована в майбутнє, яка пов'язана з прогнозуванням, передбаченням, очікуванням можливих невдач, із формуванням відповідних відношень і установок (Карвасарський, 2006). Інтенсивна тривога заважає адекватно оцінити ситуацію, визначити можливі варіанти їі розвитку і вибрати найправильніше за даних обставин рішення. Страх, паніка у провізора (фармацевта) розривають його комунікацію з пацієнтом, руйнують психологічний контакт між ними. Тривога провізора (фармацевта) «передається» відвідувачу аптеки i додатково дезорганізує його. Провізори (фармацевти) з високою особистісною тривожністю, схильні реагувати на будь-які змі- 
ни підвищенням тривоги, зазвичай малопривабливі для відвідувачів аптеки, які надають перевагу більш стабільним і емоційно врівноваженим провізорам (фармацевтам).

Другою характеристикою провізора (фармацевта), що руйнує його комунікацію з пацієнтом, може бути депресивність. Провізор (фармацевт), схильний до депресивних реакцій, не викликає довіри у хворого. Спостерігаючи, як провізор на будь-яку, навіть найнезначнішу, невдачу, неточність, помилку реагує почуттям вини, хворий починає підозрювати його в некомпетентності, перестає йому довіряти.

Третьою психологічною характеристикою, що утруднює встановлення довірливих відносин «провізор - хворий», є глибока інтровертованість провізора (фармацевта). Інтровертована особистість, занурена у свій психологічний світ, зайнята собою, своїми почуттями, ідеями, враженнями, мало цікавиться іншими людьми, виявляючи безпорадність у ситуації, що вимагає взаємодії та співробітництва з оточуючими. Як правило, інтровертованість супроводжується недостатністю інтуїції, чутливості, тактовності в міжособистісних стосунках, низьким рівнем емпатії з недостатньою здатністю відкликатися на біль і страждання іншого, його неспокій і тривогу (Б. Братусь, 1988).

Четвертою психологічною характеристикою, що знижує комунікативну компетентність провізора (фармацевта), є конфліктність.

«Конфліктність особистості» - це риса характеру, що сприяє частоті виникнення конфлікту і конфліктної взаємодії. Конфліктність особистості визначається дією таких психологічних чинників, як особливість темпераменту, рівень агресивності, компетентність у спілкуванні, емоційний стан. А також низкою соціальних чинників - умовами життя і діяльності, середовища і соціального оточення, загального рівня культури. Отже, конфліктність - це комплексний показник, пов'язаний з особистісними пере- 
думовами. Конфліктність диференціюється на ситуативну й особистісну. Ситуативна конфліктність - почуття невизначеності, невпевненості, стомлення, нестійкість настрою, підвищена збудливість, стан навіюваності. Особистісна конфліктність: знижена самокритичність, невихованість, нестриманість у почуттях, схильність до агресивної поведінки, егоїзм. Вирішення проблеми конфліктних особистостей є одним із найскладніших завдань, що виникають перед керівником і працівником аптеки. Провізор (фармацевт) у процесі трудової діяльності взаємодіє 3 різними типами конфліктних особистостей. Особистісна конфліктність провізора (фармацевта) унеможливлює ефективну комунікацію з відвідувачами аптеки, особливо з конфліктними особистостями (Филлипова, 2007).

Отже, щоб запобігти виникненню конфліктної ситуації в спілкуванні з відвідувачами аптеки, фармацевтичному працівникові слід знати типи конфліктних особистостей i деонтологічну тактику взаємодії з ними та стилі конфліктної взаємодії. Так, зарубіжні дослідники активно дослідили особливості спілкування майбутніх медиків у конфліктах і дійшли висновку, що лише невелика кількість досліджуваних (усього 9,8\%) застосовує стиль співробітництва - він вимагає багато часу і спеціальної підготовки до продуктивного виходу з конфлікту із взаємним задоволенням потреб та інтересів усіх учасників конфлікту. Найбільша кількість аспірантів і студентів-провізорів (50,2\%) вдавалася саме до компромісу як стилю врегулювання суперечностей через взаємні поступки. В уникненні брало участь $40 \%$ учасників дослідження. Цей стиль передбачає повну відмову від стосунків, є втечею від проблем і відповідальності. Натомість конструктивну комунікативну діяльність фармацевта в конфліктній взаємодії може забезпечити лише стиль співпраці (Sportsman, 2002: 159-165).

Розглянуті вище компоненти комунікативної компетентності (мотиваційний, когнітивний і професійно-кому- 
нікативний) є вагомими для успішної професійної діяльності фармацевта. Вони тісно взаємопов'язані в робочих ситуаціях провізора. Проте діяльність фармацевтичного працівника є певною мірою стресовою. Тому важливо досліджувати ще й емоційний компонент. Із результатів зарубіжних досліджень слідує, що позитивні емоційні ставлення фармацевтичного працівника до своєї роботи, зокрема його загальне задоволення професійною діяльністю, пов'язані з професійною відповідальністю, наявністю достатніх комунікативних навичок для виконання професійних обов’ язків, стресостійкістю (Yip \& Martin, 2006).

Психологічне забезпечення комунікативно-професійної діяльності майбутніх фармацевтів здійснюється ще на початкових етапах їх професіоналізації на основі детального вивчення психологічних аспектів комунікації (Candlin, 2004; Engestrom, 2005; Laurence, 2006; Umurzakhova, 2016; Zubin, 2009). Завдяки цьому комунікативна професійна діяльність провізорів (фармацевтів) є конкурентоспроможною в умовах динамічних соціальних змін. До того ж, формується деонтологічна культура майбутніх фахівців, комунікативний потенціал для їхньої професійної самореалізації й співпраці з соціальними партнерами не лише в Україні, а й за її межами.

Перспективним для подальших наукових пошуків у цьому напрямку є емпіричне дослідження психологічних особливостей, які формують комунікативну компетентність у фахівців фармацевтичної галузі, з метою їх розвитку та вдосконалення.

\section{Висновки}

Діяльність фармацевтичного працівника супроводжується тривалим спілкуванням і великим психологічним навантаженням, пов' язаним із вимогами щодо професійної та комунікативної компетентності фахівця, відповідальністю за результати діяльності, важкими психологічно напруженими умовами праці. Провізор (фармацевт) спіл- 
кується з різними людьми, часто хворими, стурбованими своїм станом здоров'я чи станом здоров'я своїх близьких, що впливає на стан їх психологічного благополуччя та поведінку. Тому фармацевтичний працівник повинен володіти знаннями з психологї̈, знати: психологічні особливості хворої людини, особи похилого віку, конфліктної особистості та деонтологічну тактику в роботі з ними. Провізор (фармацевт) повинен бути комунікативно компетентним, володіти вербальною та невербальною мовами комунікації.

Теоретичне дослідження психологічних особливостей професійної комунікативної діяльності фармацевтичного працівника, зокрема комунікативної компетентності, ми здійснювали в межах інформаційного, лінгвістичного та діяльнісного наукових підходів. Інформаційний підхід націлений на вивчення засобів спілкування, характеристик комунікаторів і вивчення особливостей прийому та передачі інформації. Лінгвістичний підхід передбачає вивчення сфери мовної діяльності людини, розглядаючи мовний акт як основу комунікації. Діяльнісний підхід передбачає спроможність сприйняття й опрацювання отриманої інформації.

Теоретичний аналіз дав нам підстави виокремити основні психологічні якості особистості, які формують комунікативну компетентність фармацевтичного працівника. До них належать:

- уміння спілкуватися, встановлювати і розвивати взаємостосунки з іншими людьми;

- прагнення знаходитися разом з іншими людьми, належати до якої-небудь соціальної групи, встановлювати емоційні взаємовідносини з оточуючими, бути в системі міжособистісних відносин (афіліація);

- емоційна стабільність, урівноваженість за відсутності імпульсивності, надмірної емоційної експресивності, зі збереженням контролю над емоційними реакціями і поведінкою загалом; 
- уміння «читати» і використовувати в професійній діяльності невербальну мову комунікації (пози, міміка, жести, погляд);

- комунікативна толерантність (як один $з$ аспектів комунікативної компетентності) - терпимість, поблажливість тощо;

- сенситивність до відхилення (знехтування) - здатність сприймати негативне ставлення оточуючих, зокрема відвідувачів аптеки.

До психологічних особливостей особистості, які знижують комунікативну компетентність провізора (фармацевта), за даними наукових досліджень, відносять тривогу, депресивність, інтровертованість, конфліктність.

Результати аналізу наукових досліджень дали підстави виокремити інформаційний, лінгвістичний і діяльнісний наукові підходи до визначення сутності комунікативної компетентності фармацевтичних працівників. Інформаційний підхід націлений на вивчення засобів спілкування, характеристик комунікаторів і вивчення особливостей прийому та передачі інформації. Лінгвістичний підхід передбачає вивчення сфери мовної діяльності людини, розглядаючи мовний акт як основу комунікації.

\section{Література}

Альохіна Н. В. Формування комунікативної компетентності майбутніх фахівців. Проблели сучасної педагогічної освіти. Ялта : РВВ КГУ, 2013. Вип. 40. Ч. 2. С. 51-56.

Зимняя И. А. Компетентность и проблемы ее формирования в системе непрерывного образования (школа - вуз - послевузовское образование). Актуальные проблемы качества образования и пути их решения: материалы XVI научно-летодической конференции / Отв. ред. И. А. Зимняя. Москва : Исследовательский центр проблем качества подготовки специалистов, 2006. 130 с.

Кайдалова Л. Г. Професійна підготовка майбутніх фахівців фармацевтичного профілю у вищих навчальних закладах: монографія. Харків : НФаУ, 2010. $364 \mathrm{c}$.

Кайдалова Л. Г., Пляка Л. В. Психологія спілкування: навч. посіб. Харків : НФаУ, 2011. 132 с. 
Клиническая психология : учебник для студентов медицинских вузов и факультетов клинической психологии / В. А. Абабков и др.; под ред. Б. Д. Карвасарского. Санкт-Петербург : Питер. 2006. 959 с.

Максименко С. Д., Заброцький М. М. Технологія спілкування (комунікативна компетентність учителя: сутність і шляхи формування). Київ : Главник, 2005. 112 с.

Москаленко В. В. Соціальна психологія: підручник. 2-ге вид., доповн. і переробл. Київ : Центр учбової літератури, 2008. 688 с.

Пляка Л. В., Тюріна В. О. Психологічні аспекти професійної комунікативної компетентності майбутнього провізора. Проблели загальної та педагогічної психологї. Київ, 2009. Т. ХІ. Ч. 4. С. 438-446.

Пляка Л. В. Психологічні аспекти професійного спілкування провізора. Наукові записки Харківського університету Повітряних Сил. Соціальна філософія, психологія. Харків : ХУПС, 2009. Вип. 2 (33). C. 204-208.

Филлипова А. Е Как избежать конфликтов в аптеке? Фарлаиевт-практик. 2007. № 1. С. 47-49.

Шматенко О. П., Гончаренко Н. В., Гончаренко І. Ф. Психологія і деонтологія у фармації: навч. посіб. Київ : «МП Леся», 2014. 132 с.

Alldredge, Brian K., Corelli, Robin L., Ernst, Michael E., et al. (Eds.). (2013). Koda-Kimble and Young's applied therapeutics: the clinical use of drugs. 10th ed. New York : Lippincott Williams \& Wilkins.

American Medical Association (2000). Code of Medical Ethics. Chicago : AMA Press.

Ashley, B. (Ed.). (2000). Ethics of Health Care: an introductory textbook. Chicago : Georgetown University Press.

Attribution, communication behaviour, and close relationship. 2001. Cambridge: Cambridge University Press. Retrieved from https:// www.cambridge.org/vi/academic/subjects/psychology/socialpsychology/attribution-communication-behavior-and-closerelationships? format $=\mathrm{PB}$.

Austin, Z., Gregory, P. A., \& Martin, C. (2009). A conflict management scale for pharmacy. American journal of pharmaceutical education, $73(7), 42-45$.

Austin Z., Gregory P. A. M., \& Martin, J. C. Pharmacists' management of conflict in community practice. Res Soc Admin Pharm., 49 (1), 16-29.

Bernstein, B. (1979). Social class, language and socialization. Language and social context: selected readings. Harmondsworth : Penguin. P. 157-178.

Bratishko, Y. S., Posylkina, O. V., \& Kubasova, A. V. (2014). Modern state of personnel management in pharmaceutical enterprises. Nürnberg. P. 148-151. 
Brown, G., \& Yul, G. (1983). Discourse Analysis. Cambridge : Cambridge University Press.

Brown, P., \& Levinson, S. (1978). Universale in Language Usage: Politeness Phenomena. Questions and Politeness: Strategies in Social Interaction. Cambridge : Cambridge University Press.

Buerki, R. A., \& Vottero, L. D. (2002). Ethical responsibility in pharmacy practice. Madison, Wisconsin : Amer. Inst. History of Pharmacy. $253 \mathrm{p}$.

Candlin, S. (2002). Taking risks: An indicator of expertise? Research on language and social interaction, 35 (2), 173-193.

Candlin, S. (2003). Issues arising when the professional workplace is the site of applied linguistic research. Applied Linguistics, 24 (3), 386394.

Cicourel, A. V. (1985). Doctor-patient discourse. Handbook of discourse analysis, 4, 193-201.

Cicourel, A. V. (2004). Language and medicine. Language in the USA. Cambridge : Cambridge University. P. 407-429.

Datkhayev, U., Shopabayeva, A., Zhakipbekov, K., Shertaeva, C., Umurzakhova, G., Sultanbekov, A., \& Tulegenova, A. (2016). Determination of Seasonal Demand for Pharmaceutical Staff. International Journal of Pharmaceutical Sciences Review and Research, 36 (2), 105-111.

Deveugele, M., Derese, A., De Maesschalck, S., Willems, S., Van Driel, M., \& De Maeseneer, J. (2005). Teaching communication skills to medical students, a challenge in the curriculum? Patient education and counseling, 58 (3), 265-270.

Donald, G. (1992). Ellis Language and Discourse Processes from language to communication. Lawrence Erlbaum Associates publishers Hillsdale. New Jersey : University of Hartford.

Engeström, Y., Engeström, R., \& Kerosuo, H. (2003). The discursive construction of collaborative care. Applied linguistics, 24 (3), 286-315.

Ethics of Health Care: an introductory textbook (2000). Chicago : Georgetown University Press. $272 \mathrm{p}$.

Evans, S. (2009). Providing maximal patient care, improving patient safety: Being good isn't always good enough. Journal of the American Pharmacists Association, 49, 489-491. Retrieved from http://www. japha.org/article/S1544-3191(15)31022-0/pdf.

Faerch, S., \& Kasper, G. (1987). Strategies in Interlanguage Communication. London : Longman Pub Group.

Fremon, B., Negrete, V. F., Davis, M., \& Korsch, B. M. (1971). Gaps in doctor-patient communication: Doctor-patient interaction analysis. Pediatric Research, 5 (7), 298-312.

Kunzmann, C., \& Schmidt, A. (2006). Ontology-based competence management for healthcare training planning: a case study. Proceedings 
of I-KNOW International conference on knowledge management, 6 , 143-150. Graz.

Latif, D. A. (2000). Cognitive moral development and pharmacy education. American Journal of Pharmaceutical Education, 64 (4), 451-454.

Laurence, L. (2006). The Pharmacological Basis of Therapeutics. New York : McGraw, Hill Medical. 2021 p.

Magola, E. (2018). Identifying the challenges faced by novice independent ice community pharmacist and developing a peer support invention to ease their transitions practitioners. Retrieved from https://www. research.manchester.ac.uk/portal/files/68670486/FULL_TEXT. PDF.

Maio, V., Goldfarb, N. I., \& Hartmann, C. W. (2004). Pharmacists' job satisfaction: variation by practice setting. $P \& T, 20(3), 184-190$.

Onufriieva, L. A. (2017). Psychological principles of foreign-language communicative competence formation belonging to future specialists in socionomic professions. Problems of Modern Psychology. Collection of research papers of Kamianets-Podilskyi National Ivan Ohiienko University, G. S. Kostiuk Institute pf Psychology of the National Academy of Educational Sciences of Ukraine, 38, 301-314. Kamianets-Podilskyi : Aksioma.

Onufriieva, L. A. (2017). The Psychology of Professional Realization of a Future Specialist's Personality: Theoretical and Methodological Aspect. Rzesz w : BonusLiber. ISBN 978-83-65441-83-6.

Pandya, H. (2011). Professionalism and Communication in Medical Practice. Medicine Update, 545-548.

Singer, P. (2005). Practical ethics. Cambridge : Cambridge University press. $395 \mathrm{p}$.

Sportsman, S., \& Hamilton, P. (2002). Conflict management styles in the health professions. Journal of professional nursing, 23 (3), 157-166.

Strand, L. M., Cipolle, R. J., Morley, P. C., \& Frakes, M. J. (2004). The impact of pharmaceutical care practice on the practitioner and the patient in the ambulatory practice setting: twenty-five years of experience. Current pharmaceutical design, 10 (31), 3987-4001.

Veatch, R. M., Haddad, A. M., \& Last, E. J. (2008). Case studies in pharmacy ethics. Oxford University Press. 311 p.

Wloszczak-Szubzda, A., \& Jarosz, M. J. (2013). Professional communication competences of physiotherapists-practice and educational perspectives. Annals of Agricultural and Environmental Medicine, 20 (1), 189-194.

Yip, J. A., \& Martin, R. A. (2006). Sense of humor, emotional intelligence, and social competence. Journal of Research in Personality, 40 (6), 1202-1208. 


\section{References}

Alokhina, N. V. (2013). Formuvannia komunikatyvnoi kompetentnosti maibutnikh fakhivtsiv [Formation of communicative competence of future specialists]. Problemy suchasnoi pedahohichnoi osvity - Problems of modern pedagogical education, 40 (2), 51-56. Yalta : RBB KHU [in Ukrainian].

Zimnjaja, A. (2006). Kompetentnost' i problemy eje formirovanija v sisteme nepreryvnogo obrazovanija (shkola - vuz - poslevuzovskoe obrazovanie) [Competence and problems of its formation in the system of continuous education (school - higher educational establishment postgraduate education]. Aktual'nye problemy kachestva obrazovanija i puti ih reshenija - Actual problems of quality of education and ways of their solution: Proceedings of XVI scientific and methodical conference. (pp. 120-130). Moskva : Issledovatel'skij tsentr problem kachestva podgotovki spetsialistov [in Russian].

Kaidalova, L. H. (2010). Profesiina pidhotovka maibutnikh fakhitsiv farmatsevtychnoho profiliu $u$ vyshchykh navchalnykh zakladakh [Professional training of future specialists in the pharmaceutical industry in higher education institutions]. Kharkiv : NFau [in Ukrainian].

Kaidalova, L. H., \& Pliaka, L. V. (2011). Psykholohiia spilkuvannia [Psychology of communication]. Kharkiv : NFau [in Ukrainian].

Karvasarskij, B. D. (Ed.) (2006). Klinicheskaja psihologija [Clinical psychology]. Sankt-Peterburg : Piter [in Russian].

Maksymenko, S. D., Zabrotskyi, M. M. (2005). Tekhnolohiia spilkuvannia (komunikatyvna kompetentnist vchytelia: sutnist $i$ shliakhy formuvannia) [Communication technology (the communicative competence of the teacher:the essence and ways of formation]. Kyiv : Hlavnyk [in Ukrainian].

Moskalenko, V. V. (2008). Sotsialna psykholohiia [Social Psychology]. Kyiv: Tsentr uchbovoi literatury [in Ukrainian].

Pliaka, L. V., \& Tiurina, V. O. (2009). Psykholohichni aspekty profesiinoi komunikatyvnoi kompetentnosti maibutnoho provizora [Psychological aspects of professional communicative competence of the future pharmacist]. Problemy zahalnoi ta pedahohichnoi psykholohii Problems of general and pedagogical psychology, 4, XI, 438-446 [in Ukrainian].

Pliaka, L. V. (2009). Psykholohichni aspekty profesiynoho spilkuvannia provizora [Psychological aspects of professional communication of pharmacist]. Naukovi zapysky Kharkivskoho universytetu Povitrianykh Syl. Sotsialna filosofiia, psykholohiia - Scientific notes of the Kharkiv University of Air Forces. Social philosophy, psychology, 2 (33), 204-208 [in Ukrainian]. 
Fillipova, A. (2007). Kak izbezhat' konfliktov v apteke [How to avoid conflicts in pharmacies]. Farmatsevt-praktyk-Pharmacist-practitioner, 1, 47-49 [in Russian].

Shmatenko, O. P., Honcharenko, N. V., \& Honcharenko, I. F. (2014). Psykholohiia $i$ deontolohiia u farmatsii [Psychology and deontology in pharmacy]. Kyiv : "MP Lesia» [in Ukrainian].

Alldredge, Brian K., Corelli, Robin L., Ernst, Michael E., et al. (Eds.). (2013). Koda-Kimble and Young's applied therapeutics: the clinical use of drugs. 10th ed. New York : Lippincott Williams \& Wilkins.

American Medical Association (2000). Code of Medical Ethics. Chicago : AMA Press.

Attribution, communication behaviour, and close relationship (2001). Cambridge: Cambridge University Press. Retrieved from https:// www.cambridge.org/vi/academic/subjects/psychology/socialpsychology/attribution-communication-behavior-and-closerelationships? format $=\mathrm{PB}$.

Ashley, B. (Ed.). (2000). Ethics of Health Care: an introductory textbook. Chicago : Georgetown University Press.

Austin, Z., Gregory, P. A., \& Martin, C. (2009). A conflict management scale for pharmacy. American journal of pharmaceutical education, $73(7), 42-45$.

Austin Z., Gregory P. A. M., \& Martin, J. C. Pharmacists' management of conflict in community practice. Res Soc Admin Pharm., 49 (1), 16-29.

Bernstein, B. (1979). Social class, language and socialization. Language and social context: selected readings. Harmondsworth : Penguin.

Bratishko, Y. S., Posylkina, O. V., \& Kubasova, A. V. (2014). Modern state of personnel management in pharmaceutical enterprises. Nürnberg.

Brown, G., \& Yul, G. (1983). Discourse Analysis. Cambridge : Cambridge University Press.

Brown, P., \& Levinson, S. (1978). Universale in Language Usage: Politeness Phenomena. Questions and Politeness: Strategies in Social Interaction. Cambridge : Cambridge University Press.

Buerki, R. A., \& Vottero, L. D. (2002). Ethical responsibility in pharmacy practice. Madison, Wisconsin : Amer. Inst. History of Pharmacy.

Candlin, S. (2002). Taking risks: An indicator of expertise? Research on language and social interaction, 35 (2), 173-193.

Candlin, S. (2003). Issues arising when the professional workplace is the site of applied linguistic research. Applied Linguistics, 24 (3), 386394.

Cicourel, A. V. (1985). Doctor-patient discourse. Handbook of discourse analysis, 4, 193-201.

Cicourel, A. V. (2004). Language and medicine. Language in the USA. Cambridge : Cambridge University. 
Datkhayev, U., Shopabayeva, A., Zhakipbekov, K., Shertaeva, C., Umurzakhova, G., Sultanbekov, A., \& Tulegenova, A. (2016). Determination of Seasonal Demand for Pharmaceutical Staff. International Journal of Pharmaceutical Sciences Review and Research, 36 (2), 105-111.

Deveugele, M., Derese, A., De Maesschalck, S., Willems, S., Van Driel, M., \& De Maeseneer, J. (2005). Teaching communication skills to medical students, a challenge in the curriculum? Patient education and counseling, 58 (3), 265-270.

Donald, G. (1992). Ellis Language and Discourse Processes from language to communication. Lawrence Erlbaum Associates publishers Hillsdale. New Jersey : University of Hartford.

Engeström, Y., Engeström, R., \& Kerosuo, H. (2003). The discursive construction of collaborative care. Applied linguistics, 24 (3), 286-315.

Ethics of Health Care: an introductory textbook (2000). Chicago : Georgetown University Press.

Evans, S. (2009). Providing maximal patient care, improving patient safety: Being good isn't always good enough. Journal of the American Pharmacists Association, 49, 489-491. Retrieved from http://www. japha.org/article/S1544-3191(15)31022-0/pdf.

Faerch, S., \& Kasper, G. (1987). Strategies in Interlanguage Communication. London : Longman Pub Group.

Fremon, B., Negrete, V. F., Davis, M., \& Korsch, B. M. (1971). Gaps in doctor-patient communication: Doctor-patient interaction analysis. Pediatric Research, 5 (7), 298-312.

Kunzmann, C., \& Schmidt, A. (2006). Ontology-based competence management for healthcare training planning: a case study. Proceedings of I-KNOW International conference on knowledge management, 6 , 143-150. Graz.

Latif, D. A. (2000). Cognitive moral development and pharmacy education. American Journal of Pharmaceutical Education, 64 (4), 451-454.

Laurence, L. (2006). The Pharmacological Basis of Therapeutics. New York : McGraw, Hill Medical.

Magola, E. (2018). Identifying the challenges faced by novice independent ice community pharmacist and developing a peer support invention to ease their transitions practitioners. Retrieved from https://www. research.manchester.ac.uk/portal/files/68670486/FULL_TEXT. PDF.

Maio, V., Goldfarb, N. I., \& Hartmann, C. W . (2004). Pharmacists' job satisfaction: variation by practice setting. $P \& T, 20$ (3), 184-190.

Onufriieva, L. A. (2017). Psychological principles of foreign-language communicative competence formation belonging to future specialists in socionomic professions. Problems of Modern Psychology. Collec tion of research papers of Kamianets-Podilskyi National Ivan Ohiienko University, G. S. Kostiuk Institute pf Psychology of the National 
Academy of Educational Sciences of Ukraine, 38, 301-314. Kamianets-Podilskyi : Aksioma.

Onufriieva, L. A. (2017). The Psychology of Professional Realization of a Future Specialist's Personality: Theoretical and Methodological Aspect. Rzesz w : BonusLiber. ISBN 978-83-65441-83-6.

Pandya, H. (2011). Professionalism and Communication in Medical Practice. Medicine Update, 545-548.

Singer, P. (2005). Practical ethics. Cambridge : Cambridge University press.

Sportsman, S., \& Hamilton, P. (2002). Conflict management styles in the health professions. Journal of professional nursing, 23 (3), 157-166.

Strand, L. M., Cipolle, R. J., Morley, P. C., \& Frakes, M. J. (2004). The impact of pharmaceutical care practice on the practitioner and the patient in the ambulatory practice setting: twenty-five years of experience. Current pharmaceutical design, 10 (31), 3987-4001.

Veatch, R. M., Haddad, A. M., \& Last, E. J. (2008). Case studies in pharmacy ethics. Oxford University Press.

Wloszczak-Szubzda, A., \& Jarosz, M. J. (2013). Professional communication competences of physiotherapists-practice and educational perspectives. Annals of Agricultural and Environmental Medicine, 20 (1), 189-194.

Yip, J. A., \& Martin, R. A. (2006). Sense of humor, emotional intelligence, and social competence. Journal of Research in Personality, 40 (6), 1202-1208.

\section{Гончаренко Наталія. Психологічні особливості професійної комуніка- тивної діяльності фармацевтичного працівника}

\section{АНОТАЦІЯ}

У статті викладено результати аналізу наукових джерел із теоретико-методологічних і прикладних аспектів проблематики. Визначено сутність і специфіку професійної комунікативної діяльності майбутніх провізорів, охарактеризовано їх професійні комунікативні якості mа здібності, психологічні характеристики особистості, що формують комунікативну компетентність майбутнього провізора (фрармацевта). Підкреслено, що комунікативна компетентність провізора (фрармацевта) - професійно значуща якість, оскільки його професійна діяльність передбачає спілкування: з хворими, їх родичами, лікарями. Зазначено, що професійні комунікативні якості провізорів становлять психологічний портрет майбутніх провізорів. Наголошено, що складниками професійної комунікативної компетентності майбутніх провізорів є мотиваційний, когнітивний і професійно-комунікативний 
компоненти, які відіграють роль критеріїв ії розвитку. Визначено основні умови формування комунікативної компетентності майбутнього фрармацевтичного прачівника. Констатовано, що серед професійно значущих психологічних характеристик особистості фармачевтичного працівника можна виокремити уміння спілкуватися, встановлювати і розвивати взаємостосунки з іншими людьми, емоційну стабільність, урівноваженість за відсутності імпульсивності, надмірної емоційної експресивності, вміння «читати» і використовувати в професійній діяльності невербальну мову комунікації, комунікативну толерантність, сенситивність до відхилення (знехтування). Окреслено професійно важливі для фрармацевтичного працівника параметри паралінгвістичної комунікації й особливості використання засобів невербальної мовної комунікації у їх професійній діяльності.

Ключові слова: комунікація, комунікативна діяльність майбутніх провізорів, компетентність, професійна компетентність, професійна комунікативна компетентність, комунікативна толерантність, афіліація, невербальна мова комунікації.

\section{ГончаренкоНаталия. Психологическиеособенностипрофессиональной коммуникативной деятельности фармацевтического работника}

\section{АННОТАЦИЯ}

В статье изложены результаты анализа научных источников с теоретико-методологических и прикладных аспектов проблематики. Определены сущность и специфика профессиональной коммуникативной деятельности будущих провизоров, охарактеризовано их професссиональные коммуникативные качества и способности, психологические характеристики личности, которые формируют коммуникативную компетентность будущего провизора (фрармацевта). Подчеркнуто, что коммуникативная компетентность провизора (фармацевта) профессионально значимое качество, так как его профессиональная деятельность предполагает общение: с больными, их родственниками, врачами. Подчеркнуто, что профессиональные коммуникативные качества провизоров составляют психологический портрет будущих провизоров. Отмечено, что составляющими профессиональной коммуникативной компетентности будущих провизоров являются мотивационный, когнитивный и профессионально-коммуникативный компоненты, которые играют роль критериев ее развития. Определены основные условия формирования коммуникативной компетентности 
будущего фармацевтического работника. Констатировано, что среди профессионально значимых психологических характеристик личности фармацевтического работника можно выделить умение общаться, устанавливать и развивать взаимоотношения с другими людьми, эмоциональную стабильность, уравновешенность при отсутствии импульсивности, чрезмерной эмоциональной экспрессивности, умение "читать» и использовать в профессиональной деятельности невербальный язык коммуникации, коммуникативную толерантность, сенситивность к отклонению (пренебрежению). Очерчено профрессионально важные для фрармацевтического работника параметры паралингвистической коммуникации и особенности использования средств невербальной речевой коммуникации в их профессиональной деятельности.

Ключевые слова: коммуникация, коммуникативная деятельность будущих провизоров, компетентность, профессиональная компетентность, профессиональная коммуникативная компетентность, коммуникативная толерантность, аффилиация, невербальный язык коммуникации. 